\title{
OMBUDSMAN: SUATU KAJIAN ANALISIS
}

\author{
Yeni Sri Lestari \\ Fakultas Ilmu Sosial dan Ilmu Politik Universitas Teuku Umar \\ yenilestari24@yahoo.com
}

\begin{abstract}
This article analyzes the history and role of the Ombudsman in improving the quality of public service delivery by government officials of a country. The establishment of the Ombudsman is an important step that is done to balance the performance of the apparatus of government in providing public services and justice to the people. This study is important as a reference many countries are working to improve the quality of public services personnel administration. Therefore, the discussion in this article is what is meant by the Ombudsman? How Ombudsman formed? The second is how the performance of the Ombudsman? And how is the impact of the Ombudsman? This study found that the background of the establishment of Ombudsman first appeared in Sweden is based on the Swedish government's efforts to create a balance of public services by government officials and the general public to the demands of globalization and democracy today. At the end of the study it was found that by taking a study on the Ombudsman parliamentary in New Zealand and the United Kingdom found that the practice of the concept of Ombudsman institutions have a positive impact to the management of the public service, it then becomes the impetus for other countries to participate in establishing the Ombudsman.
\end{abstract}

Keywords: Ombudsman, New Zealand, United Kingdom 


\section{PENDAhUluAN}

Kajian mengenai lembaga Ombudsman merupakan salah satu kajian penting dalam sistem pelayanan publik negara pada masa kini. Kehadiran lembaga Ombudsman telah melahirkan sistem penyelenggaraan pelayanan publik yang sangat berkesan positif bagi keseimbangan pelayanan yang diberikan oleh aparatur pemerintahan kepada masyarakat banyak. Sejarah telah membuktikan kehadiran Ombudsman menciptakan keberhasilan sistem pelayanan publik yang baik di beberapa negara, hal ini dapat dilihat dari semakin banyak negara yang mendirikan Ombudsman sebagai salah satu lembaga kekuasaan negara, Swedia pada tahun 1809 yang kemudian diikuti oleh negara Scandinavia lainnya, New Zealand pada tahun 1962, United Kingdom pada tahun 1967, dan Australia pada tahun 1971.

Terdapat beberapa faktor yang mendorong berdirinya lembaga Ombudsman di beberapa negara,salah satunya adalah dorongan dari semakin mapannya sistem demokrasi disebagian besar negara.Perkembangan demokrasi telah membawa perubahan yang cukup besar bagi keterbukaan dan kebebasan masyarakat. Keterbukaan dalam pelbagai aspek kehidupan terutama pendidikan telah menciptakan perkembangan pola pikir masyarakat untuk lebih aktif dalam mengusung tema-tema hak dan kebaikan yang dituntut dari lembaga/institusi/organisasi negara.

Sistem pendidikan yang semakin dan terus maju serta dorongan akan penguasaan ilmu pengetahuan telah merubah pola pikir masyarakat ketahapan yang lebih kritis. Hal ini dapat dilihat dari kekritisan masyarakat terhadap hal-hal yang berkaitan dengan hak ataupun kebijakan yang ditetapkan oleh negara akan ditentang apabila tidak sesuai dengan keadaan dan kondisi masyarakat.

Masyarakat sekarang ini mampu untuk menuntut pelbagai hal mengenai hak yang dahulunya dianggap tidak dapat diperdebatkan dengan penyelenggara kebijakan publik namun sekarang menjadi hal yang biasa diperdebatkan. Hal ini dikarenakan pemikiran masyarakat yang mulai terbuka, matang dan lebih berwawasan dalam menilai setiap aturan dan tindakan, sehingga masyarakat memiliki kesadaran untuk membela kepentingannya, terutama kepentingan yang menyangkut kehidupan masyarakat banyak.

Negara sebagai penyelenggara pelayanan publik harus mampu memberikan pelayanan yang baik dan maksimal kepada seluruh lapisan masyarakat. Sistem pelayanan yang diberikan bukanlah sistem pelayanan yang hanya mementingkan segolongan orang atau sekumpulan kelompok saja, namun harus mempertimbangkan kebaikan bersama.

Sistem demokrasi yang memberikan kebebasan yang sangat luas juga kepada aparatur negara seringkali menyebabkan penyalahgunaan kekuasaan. Penyalahgunaan kekuasaan yang kerap terjadi di kalangan aparatur negara ialah praktik maladministrasi dan korupsi. Walaupun sebagian besar negara memiliki aturan hukum yang jelas terkait sistem pelayanan dan korupsi namun masih terdapat praktik-praktik curang yang terjadi dalam sistem pelayanan publik.

Keadaan seperti itu telah mendorong untuk dibentuknya sebuah lembaga negara yang dapat mengontrol kinerja aparatur negara dalam memberikan pelayanan publik secara maksimal dan berkesan kepada masyarakat. Oleh karena itu, terbentuklah Ombudsman sebagai lembaga independen negara yang bertujuan untuk memberikan perlindungan terhadap hak-hak masyarakat yang berkaitan dengan pelbagai macam bentuk pelayanan publik dan perlakuan dari aparatur negara yang tidak sesuai dengan kewajiban hukumnya.

\section{METODOLOGI PENELITIAN}

Penulisan ini akan membahas mengenai sejarah dan konsep mengenai Ombudsman. Kajian permasalahan ini melingkupi penyelenggaraan Ombudsman di New Zealand dan United Kingdom. penulisan ini menggunakan tehnik pengumpulan data penelitian kepustakaan dan pendapat yaitu pengumpulan data dilakukan melalui data-data yang diperoleh dari pengumpulan sumber-sumber bacaan yang meliputi buku, jurnal, dan surat kabar. 
Variabel penelitian dalam penulisan ini ialah Ombudsman dan kajian analisis. Ombudsman ialah sebuah lembaga negara yang berfungsi sebagai lembaga pengaduan masyarakat terhadap sistem pelayanan oleh pegawai pemerintahan, kajian analisis ialah pembahasan sebuah masalah menggunakan pengamatan sehingga mampu menguraikan permasalahan secara tepat. Oleh karena itu, tehnik analisis yang digunakan ialah analisis kualitatif, yaitu penelitian ini menganalisis permasalahan dan menguraikan pembahasan menggunakan kata-kata atau deskriptif.

\section{PEMBAHASAN}

\section{Ombudsman: Sejarah dan Konsep}

Ombudsman pertama kali lahir dan di kenal di Stockholm, Swedia pada tahun 1809 sebagai sosok orang yang memiliki tugas untuk melindungi kepentingan individu dari pelanggaran pelaksanaan pelayanan publik oleh aparatur negara. Ombudsman di Swedia dikenal dengan nama Justitieombudsman (ombudsman for justice/ombudsman untukkeadilan) atau procurator for civil affairs (orang yang mendapat kewenangan untuk mengurus kepentingan orang lain (prokurator) untuk urusan sipil), sedangkan secarabahasa ombudsman berarti perwakilan/agen.

Lembaga Ombudsman Swedia merupakan salah satu perangkat kontrol yang memiliki peran penting dalam mewujudkan keadilan dalam pelaksanaan pelayanan publik (terutama wibawa) dan sistem pengadilan oleh para aparatur negara. Dapat dikatakan bahwa Ombudsman berdiri dilatarbelakangi adanya keinginan untuk menciptakan keadilan yang sama rata bagi masyarakat untuk memperoleh kesamaan perlakuan dalam pelayanan publik oleh lembaga-lembaga negara maupun keadilan dalam sistem peradilan negara.

Ombudsman pada awalnya dipimpin oleh tiga orang justies Ombudsman yang dilantik oleh Riksdag atau parlemen Swedia. Ombudsman memiliki peran dan tugas untuk memperhatikan jalannya hukum dan perundang-undangan yang mengadili aparatur pemerintahan yang melakukan kesalahan, sehingga dapat dikatakan bahwa tugas pokok Ombudsman ialah untuk memastikan bahwa setiap orang yang memiliki kekuasaan menggunannya dengan semestinya, yaitu tidak berlawanan dengan hak dan kepentinganmasyarakat banyak.

Prinsip kebebasan dalam sistem demokrasi di Swedia telah membawa pelbagai keleluasaan bagi setiap individu dalam bertindak, tidak terkecuali aparatur negara. Kebebasan yang dimiliki oleh setiap orang, dalam hal ini aparatur pemerintah seringkali menimbulkan sikap yang semena-mena terhadap masyarakat sebagai objek yang harus mereka layani, hal ini timbul sebagai akibat dari beranekaragamnya sifat individu yang dapat menyebabkan perbedaan sifat dan karakter yang terkadang memunculkan pertentangan/konflik antara aparatur pemerintahan (yang melayani) dengan masyarakat (yang dilayani).

Interaksi yang terjadi antara pemberi layanan (aparatur pemerintah) dengan yang dilayani (masyarakat) dapat terjadi dalam pelbagai bentuk seperti interaksi yang baik, ramah, tamah dan sopan ataupun interaksi yang kurang berkesan dan berkenan, hal ini dapat membentuk rasa kepuasan ataupun ketidakpuasan masyarakat terhadap kinerja pelayanan publik. Pada satu sisi, aparatur pemerintah seringkali merasa memiliki kekuasaan dan wewenang yang besar dalam sebuah lembaga yang terkadang menyebabkan terjadinya penyalahgunaan kekuasaan dan maladministrasi, di sisi lain, masyarakat sebagai objek pelayanan publik dari aparatur pemerintah kerap merasakan ketidakpuasan atau diskriminasi dalam memperoleh pelayanan dan peradilan.

Usaha melindungi dan membantu masyarakat untuk mendapatkan sistem pelayanan dan peradilan yang adil maka dirumuskanlah sebuah solusi yang dapat menjadi alternatif bagi pemecahan persoalan tersebut. Oleh karena itu, untuk mendampingi dan menampung pelbagai keluhan dari masyarakat awam terhadap kinerja pelayanan aparatur pemerintahan, didirikannyalah sebuah lembaga yang efektif untuk mengontrol kinerja aparatur pemerintahan 
yang bersifat independen. Berdasarkan saran dan masukan dari masyarakat Swedia, maka wujudlah lembaga Ombudsman di Swedia pada tahun 1809.

Sebelum Ombudsman resmi terbentuk di Swedia, parlemen Swedia telah membentuk lembaga the king's highest Ombudsman yang dikenal dengan nama chancellor of justice, yang merupakan Ombudsman kerajaan (executive Ombudsman). Kemudian Ombudsman kerajaan terus berkembang hingga menjadi Ombudsman parlemen Swedia (Swedish's Parliamentary Ombudsman) yang dilegalkan dalam konstitusi negara Swedia.

Ombudsman Swedia, merupakan lembaga pengawasan yang dibentuk oleh parlemen tetapi bersifat independen dalam melaksanakan tugasnya, yaitu menerima dan menyelidiki keluhan masyarakat terkait penyelenggaraan pelayanan dan peradilan negara.Peran utama Ombudsman Swedia ialah untuk melindungi hak warga negara Swedia dari pelbagai pelanggaran yang dilakukan oleh apartur pemerintahan dan aparat penegak hukum.

Keberhasilan lembaga Ombudsman di Swedia dalam menciptakan keseimbangan dan harmoni sosial diantara masyarakat dengan aparatur pemerintah dalam urusan pelayanan publik tersebar dan meluas kepelbagai penjuru dunia terutama setelah Perang Dunia Kedua (Rowat, 1968:85). Oleh karena itu, Ombudsman Swedia telah dijadikan sebagai model lembaga yang efektif untuk mengontrol sistem pelayanan publik dari aparatur pemerintah kepada masyarakat oleh negara-negara lain, meliputi negara Scandinavia, Uni Eropa, Afrika Selatan, Asia, Australia, Pasifik, Karibia, Amerika Latin dan banyak lagi (Gregory \& Giddings, 1997:99). Berdasarkan hal tersebut, dapat dipastikan bahwa kesuksekan yang dicapai oleh Swedia dalam meningkatkan kualitas sistem pelayanan publiknya akan dapat dirasakan juga oleh negara lainnya yang turut mendirikan Ombudsman sebagai sebuah lembaga alternatif yang bertujuan untuk mengontrol kinerja aparatur pemerintah.

Amerika Serikat dalam maturation issues for the Ombudsman menguraikan bahwa meskipun kritikan terhadap kinerja pemerintah selalu meningkat di seluruh dunia, kehadiran Ombudsman telah memberikan cahaya keyakinan kepada masyarakat luas terhadap sistem pelayanan publik (Gerald Caiden, 1988: 112). Hal ini dikarenakan, sifat independen yang dimiliki oleh Ombudsman memberikan kepercayaan kepada masyarakat terhadap kinerja Ombudsman dalam menanggapi pelbagai keluhan yang disampaikan oleh masyarakat terkait pelayanan oleh aparatur pemerintah, sehingga Ombudsman tidak saja berkedudukan di tingkat pusat, melainkan daerah bahkan hingga ke tingkatan yang lebih kecil (national, state, regional or municipal levev).

Ombudsman kini ada disebahagian besar negara-negara di dunia, meskipun pada beberapa negara tidak digunakan nama yang sama, terdapat perbedaan dari penggunaan bahasa, bidang kuasa yang berbeda antar negara, namun memiliki fungsi dan konsep yang sama. Hal ini dapat dilihat dari beberapa lembaga Ombudsman yang memiliki nama lain dibeberapa negara sepertipublic protector in South Africa, Protecteur du Citoyen in Quebec, Volksanwaltschaft in Autria, Public Complaints Commision in Nigeria, Difensore Civico in Italy, Wafaqi Mohtasib in Pakistan, Lok Ayukta in India, dll (Antonius Sujata, 2003:3).

Kini, meskipun Ombudsman sudah ada sejak 200 tahun lalu namun, Ombudsman telah menjadi kajian penting dan populer sejak 50 tahun belakangan ini, terutama paska Perang Dunia Kedua. Hal ini terjadi akibat mulai munculnya kesadaran dan perhatian terhadap persoalan Hak Asasi Manusia (HAM), kemajuan pendidikan dan pengetahuan publik yang cukup pesat.

Terbentuknya Ombudsman di pelbagai negara juga turut menandai perkembangan proses demokrasi di negara tersebut dan melahirkan sebuah sistem kekuasaan baru terutama dalam bidang pengawasan selain kekuasaan dalam konsep trias politica. Pengakuan terhadap keberadaan Ombudsman juga turut dilegalkan dalam kegiatan the international commission of jurist dan PBB yang mendukung pembentukan Ombudsman di sebuah negara, hal ini didasarkan kepada pertimbangan perlunya Ombudsman untuk membantu menangani persoalanpersoalan birokrasi yang semakin kompleks. 
Seiring perkembangan dan penyebarluasan konsep Ombudsman, banyak sarjana yang mulai memberikan definisi mengenai konsep Ombudsman secara lebih relevan dengan keadaan saat ini. Dalam Encyclopaedia Britannica tahun 1972, mengartikan Ombudsman sebagai "is a legislative commissioner for the investigation of citizens' complaints of bureaucratic abuse" (Larry B. Hill, 1974: 1076-1077).

Lebih lanjut, Hill turut mendefinisikan Ombudsman secara lebih spesifik sebagai "they are includes the fact that the office can use its 'extensive powers of investigation in performing a post decision administrative audit', that the findings are reported publicly but it cannot change administrative decisions" (Larry B. Hill, 1970: 12).

Owen mendefinisikan Ombudsman sebagai "suatu lembaga kuasa yang diberikan melalui lembaga pemerintah atau badan peradilan atau parlemen yang menerima pengaduan dari masyarakat yang kurang puas terhadap lembaga negara, aparatur negara atau kinerjanya" (Owen, 1990: 5).

Sedangkan dalam The International Bar Association mengartikan Ombudsman sebagai "an office provided by the constitution or by action of the legislature or parliament and headed by independent, high-level public official who is responsible to the legislature or parliament, who receives complaints from aggrieved persons against government agencies, officials and employees or who acts on his own motion, and who has the power to investigate, recommend corrective action and issue reports" (Haller, 1998: 22).

Heede juga turut mendefinisikan Ombudsman sebagai "A reliable person who for the purposes of legal protection of individuals as well as parliamentary control supervises almost all administrative bodies and civil servants. He cannot correct their decisions, but-based on submitted complaints or on own initiatives - he may criticize them" (Heede, 2000: 18).

Konsep utama Ombudsman ialah menyediakan perlindungan bagi setiap masyarakat yang dicapai melalui pemberian peluang kepada masyarakat untuk menyuarakan kritikan atas ketidakpuasan serta kesempatan untuk menyelesaikan persoalan tersebut sebelum diajukan kedalam sistem peradilan yang rumit, proses yang lama serta biaya yang mahal. Kehadiran Ombudsman menawarkan konsep yang meringankan beban masyarakat yang memiliki perselisihan atas masalah pelayanan publik atau hukum yang melibatkan aparatur pemerintah.

Ombudsman juga menawarkan konsep pelayanan yang formal, murah, efektif, fleksibel, dan usaha membentuk kebijakan/aturan baru yang independen. Hal ini memberikan kepercayaan masyarakat terhadap Ombudsman sebagai lembaga yang ideal untuk memperjuangkan hak masyarakat memperoleh keadilan dalam pelayanan birokrasi dalam pelbagai macam bentuk ketidakpuasan, diskrimimasi maupun kritikan lainnya.

Wujudnya konsep Ombudsman menekankan kepastian bahwa seluruh aparatur pemerintah menjalankan tugas dan kewenangannya dengan adil, jujur dan bertanggung jawab. Hal demikan merupakan kewajiban yang harus dilakukan oleh Ombudsman, sehingga Ombudsman menjadi sebuah lembaga perwakilan rakyat yang memiliki ciri dan peran khusus untuk melindungi HAM dan meningkatkan kualitas sistem pelayanan publik yang berbeda dengan lembaga negara lainnya, oleh sebab itu, kajian akan konsep Ombudsman terus berkembang dan diminati oleh banyak negara.

Didapati perbedaan bahasa (nama), bidang kuasa dan fungsi yang berlainan mengenai Ombudsman di beberapa negara, namun pada dasarnya, ciri-ciri Ombudsman ialah sama. Ombudsman memiliki ciri yang meliputi kebebasan, bidang kuasa yang luas, direct access, dan mekanisme yang tepat dalam penanganan masalah (Scott, 1994: 541). Ciri-ciri Ombudsman di beberapa negara tidaklah berbeda jauh dari apa yang disebutkan oleh Scott.

Ombudsman sebagai sebuah lembaga negara memiliki tujuan untuk memberikan perlindungan terhadap HAM, di mana Ombudsman memiliki hak untuk menyelidiki, hak merumuskan solusi terhadap kasus yang telah diselidiki tetapi tidak memiliki hak untuk membuat keputusan terhadap legally binding force (Scott, 1994: 541). Hak luas yang dimiliki 
Ombudsman untuk menindaklanjuti keluhan atau kritikan yang diberikan oleh masyarakat diproses melalui beberapa tahapan.

Tahapan tersebut meliputi pelaporan atau aduan, penyelidikan, setelah proses penyelidikanmaka Ombudsman berhak memberikan masukan berupa saran kepada lembaga/aparatur negara yang bersangkutan untuk dijadikan sebagai bahan pertimbangan dalam menindaklanjuti adanya unsur penyalahgunaan kuasa yang terjadi. Namun, hak Ombudsman dibatasi hingga pemberian saran kepada lembaga/aparatur negara yang berkaitan saja, sedangkan untuk membuat keputusan yang mengikat kuasa legal ialah dikembalikan kepada kewenangan lembaga negara tersebut.

Keanggotaan Ombudsman tidak khusus dan tetap, melainkan dapat dipegang oleh satu orang atau sekelompok orang dan tidak bias gender, sehingga laki-laki maupun perempuan memiliki hak untuk bergabung dalam Ombudsman. Keanggotaan Ombudsman memiliki kualifikasi pengalaman, wibawa, keahlian dalam bidang tertentu yang dipilih berdasarkan standar yang sesuai untuk menangani persoalan ketidakpuasan ataupun kritikan masyarakat terhadap keputusan birokrasi. Ombudsman juga merupakan lembaga netral dan menjadi penengah antara pemerintah dengan masyarakat serta tidak berunsur kepartaian (Lundvik, 1968: 58). Di beberapa negara seperti United Kingdom dan New Zealand, Ombudsman dipegang oleh satu kuasa yang ditunjuk berdasarkan hasil keputusan parlemen.

Ciri Ombudsman seperti yang diuraikan di atas, menegaskan akan keefektifan dan keefesienan lembaga tersebut dalam membantu masyarakat mendapatkan haknya. Ombudsman sangat membantu masyarakat awam terutama masyarakat kecil yang ingin mendapatkan hak yang sama dalam perlakukan pelayanan maupun peradilan.

Dalam proses penyelidikan dari awal hingga akhir, pelayanan yang diberikan oleh Ombudsman tidak dikenakan pemungutan biaya apapun kepada masyarakat, serta aduan akan lebih cepat diproses dibandingkan melalui prosedur hukum yang cenderung memakan waktu lama dan biaya yang mahal. Ciri khas Ombudsman tersebut, telah menarik perhatian masyarakat umum dari pelbagai kalangan untuk menjadikan Ombudsman sebagai pilihan utama ketika berhadapan dengan ketidakpuasan pelayanan publik oleh aparatur pemerintah, selain karena Ombudsman juga merupakan lembaga yang netral atau tidak bias.

Ombudsman secara universalnya memiliki karakteristik yang meliputi; (1) lembaga pengawas eksternal terhadap pelayanan publik oleh pemerintah; (2) independen; (3) rekomendasinya bersifat legally binding; (4) ruang lingkupnya berada pada hukum publik (hukum administrasi negara); (5) mempunyai subpoena power; dan (6) bertugas mengeliminir tindakan maladministrasi dan praktek koruptif (Antonius Sujata, 2003:2). Karakteristik universal Ombudsman merupakan acuan bagi penyelenggaraan konsep Ombudsman di beberapa negara yang juga mendirikan Ombudsman walaupun dengan nama dan bidang kuasa yang berlainan antara satu negara dengan negara lainnya.

Ombudsman sebagai perangkat yang memiliki sifat akuntabilitas antara individu dan aparatur negara juga memiliki tanggung jawab untuk memberikan saran kepada pemerintah dalam menyelesaikan permasalahan. Oleh karena itu, terdapat 6 objektif utama Ombudsman, yaitu (1) untuk kesalahan individu yang benar; (2) untuk membuat birokrasi lebih berperikemanusiaan; (3) untuk mengurangi pemisahan yang kerap terjadi dari pemerintahan; (4) untuk menghindari penyalahgunaan dengan bertindak sebagai pemerhati birokrasi; (5) untuk mempertahankan bahwa aparatur pemerintah sudah berlaku tidak adil; dan (6) untuk memperkenalkan reformasi pelayanan publik (Owen, 1990).

Ombudsman merupakan lembaga negara yang memiliki fungsi tersendiri. Sebagai salah satu lembaga kekuasaan negara yang memiliki payung hukum dan ciri khasnya, Ombudsman berfungsi untuk menyelidiki dan mengintrogasi aduan-aduan masyarakat tentang kinerja aparatur pemerintah mengenai kesalahan dan ketidakadilan pemerintahan serta menjaga hak-hak rakyat dari penyelewengan yang dilakukan oleh aparatur pemerintah (Seneviratne, 2002: 32). 
Meskipun Ombudsman merupakan lembaga negara baik yang bertanggung jawab kepada eksekutif ataupun legislatif namun, Ombudsman tetap bekerja independen dalam menyelesaikan persoalan-persoalan terkait aduan masyarakat tanpa adanya campur tangan maupun pertimbangan yang condong kepada pemerintah atau partai politik.

Dalam proses peradilan, Ombudsman tidak akan melibatkan pengacara karena fungsi Ombudsman dalam sebuah negara umumnya ialah seperi complaint's lawyer yang menegaskan bahwa Ombudsman memang murni lembaga independen yang tidak terlibat atau bergantung dengan badan-badan pemerintahan lainnya (Gregory \& Giddings, 1997: 107). Selain itu, Ombudsman juga memiliki fungsi dalam access to departemental files, yaitu memiliki kuasa untuk menyimak dan memeriksa pelbagai dokumen yang berkaitan dengan aduan yang diterima mengenai sebuah lembaga/aparatur pemerintah.

Fungsi Ombudsman dijelaskan lebih rinci oleh Ramanathan (2000). Ramanathan menegaskan adanya tiga fungsi utama dari sebuah lembaga Ombudsman, yaitu pertama mengendalikan dan menyelidiki ketidakpuasan individu atau rakyat terhadap sistem administrasi pemerintahan, kedua memperbaiki sistem administrasi atau mengubah pandangan umum terhadap pemerintahan, ketiga membantu dalam tugas pembimbingan badan hukum, terutama laporan khusus dan laporan Ombudsman dapat dijadikan acuan dalam menjalankan fungsi-fungsi badan peradilan (Ramanathan, 2000: 145-146).

Perkembangan keberhasilan lembaga Ombudsman telah menciptakan pelbagai macam jenis Ombudsman dalam satu negara. Seperti Ombudsman berparlemen yang menyelidiki aduan mengenai tindakan pemerintahan lembaga-lembaga negara yang dilakukan oleh masyarakat terutama ketika masyarakat menjadi pemilih dalam proses pemilihan umum, Ombudsman berhukum/komisioner yang bertanggung jawab menyelidiki aduan tentang lembaga-lembaga tertentu atau pelayanan profesional, Ombudsman berasaskan industri yang menyelidiki aduan terhadap pelanggaran yang dilakukan oleh perusahaan yang menyediakan pelbagai macam pelayanan umum dan beberapa jenis Ombudsman lainnya.

Ombudsman berparlemen merupakan salah satu jenis Ombudsman yang populer terdapat di negara commonwealthdan Skandinavia. Untuk mendapati analisis yang lebih mendalam mengenai sistem Ombudsman berparlemen, maka New Zealand dan United Kingdom merupakan dua contoh negara yang tepat untuk dikaji lebih lanjut. Kajian ini mengambil New Zealand dan United Kingdom sebagai unit kajian didasari pertimbangan bahwa Ombudsman berparlemen di New Zealand dan United Kingdom merupakan salah satu Ombudsman terbaik yang bukan berasal dari wilayah negara Skandinavia namun berhasil menciptakan iklim positif terhadap perkembangan dan kesuksesan lembaga tersebut di negaranya.

\section{Ombudsman di New Zealand}

Ombudsman New Zealand merupakan Ombudsman keempat yang dibentuk setelah sebelumnya terdapat di negara Swedia, Finlandia dan Denmark, sehingga Ombudsman New Zealand adalah Ombudsman pertama yang terbentuk diluar wilayah Skandinavia. Secara resmi, Ombudsman New Zealand disahkan pada tahun 1962 melalui Undang-undang Komisi Parlemen (Ombudsman) tahun 1962.

Bidang kuasa Ombudsman New Zealand pada awalnya dibatasi hanya untuk menyelidiki aduan yang meliputi lembaga dan organisasi pusat saja, kemudian pada 1968 kuasa Ombudsman diperluas meliputi bidang pendidikan dan lembaga kesehatan. Hingga 1975, Ombudsman melalui Undang-undang (UU) Ombudsman Tahun 1975 mulai memperjelas dan mempertegas kedudukan Ombudsman serta lingkup penyelidikannya meluas hingga kepemerintahan dan lembaga-lembaga daerah.

Sepak terjang Ombudsman New Zealand semakin luas dan besar serta mempengaruhi setiap lini bidang pemerintahan. Juli 1983 melalui UU Informasi Resmi Tahun 1982 telah ditetapkan, di mana dalam salah satu pasal menyatakan bahwa Ombudsman diberikan fungsi untuk 
menyelidiki dan mengkaji kembali aduan mengenai keputusan yang dibuat oleh Minister of the Crown dan lembaga-lembaga pemerintahan pusat untuk membuat permintaan informasi. Ketentuan yang terdapat dalam UU tersebut, memberikan hak kepada Ombudsman untuk dapat mengakses dokumen-dokumen pemerintahan yang berkaitan dengan aduan yang diterima oleh Ombudsman, hal ini menjadi dobrakan yang besar dalam sejarah Ombudsman New Zealand.

Selain kuasa untuk mengakses dokumen resmi pemerintahan pusat, dalam meningkatkan kualitas sistem pelayanan publik di seluruh lapisan birokrasi, maka ditetapkanlah Local Government Official Information and Meetings Act 1987 yang disahkan pada Maret 1988. UU tersebut merupakan UU yang memberikan kuasa kepada Ombudsman untuk mendapatkan informasidari lembaga-lembaga daerah yang berkaitan dalam proses penyelidikan aduan dari masyarakat.

Upaya peningkatan kualitas pelayanan publik di New Zealand terus ditingkatkan melalui Protected Disclosures Act 2000 yang disahkan pada Januari 2001. UU ini dikenal sebagai UU "whistle-blower" di mana, melalui UU ini Ombudsman diberikan tanggung jawab untuk memberikan masukan dan saran serta panduan kepada pelapor (pembuat aduan) atau yang sedang mempertimbangkan untuk memberikan laporan mengenai ekspos kemungkinan telah terjadi penyimpangan yang serius di tempat kerja meraka (pegawai pemerintahan maupun swasta).

Bidang kuasa Ombudsman dalam mengontrol sistem pelayanan publik terus diperluas, melalui National Preventive Mechanism (NPM) di bawah Crimes of Torture Act (COTA) 1989 di mana COTA berwenang terhadap Optional Protocol to the Convention Against Torture (OPCAT) serta pelbagai bentuk kekejaman lain yang tidak berlandasakan perikemanusiaan. Melalui UU tersebut, Ombudsman diberikan wewenang untuk memantau kondisi tahanan di penjara, tahanan di pusat imigrasi, kesehatan dan penjara bagi tersangka yang cacat, rumah perlindungan anak-anak serta lembaga rehabilitasi kemasyarakatan lainnya untuk dipantau dan membuat laporan/saran untuk terus memperbaiki sistem pelayanan di lembaga-lembaga tersebut.

Proses pembuatan aduan

Gambar 1. cara-cara melakukan aduan ke Ombudsman New Zealand

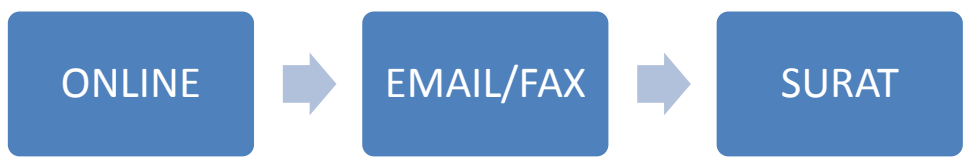

Pembuatan aduan dapat dilakukan dalam pelbagai cara, seperti yang disebutkan pada tabel di atas. Untuk melengkapi proses aduan, pelapor harus menyertakan identitas lengkap, alamat pos lengkap, informasi tentang aduan, langkah-langkah yang telah ditempuh sebelumnya untuk menyelesaikan perselisihan/persoalan tersebut, hasil yang diinginkan serta bukti dokumen yang berkaitan. Setelah berkas-berkas lengkap maka pelapor dapat memproses lebih lanjut dengan cara mengirimkan berkas tersebut ke web online/email/fax/surat pos resmi kantor Ombudsman New Zealand.

Kelengkapan dokumen pengaduan akan langsung diproses oleh Ombudsman, adapun proses yang dilakukan oleh Ombudsman dalam menyelesaikan aduan ialah; (1) Ombudsman akan menerima aduan dan menginformasikannya kepada pelapor; (2) Ombudsman akan memberikan penilaian terhadap isi aduan \& menyarankan tindakan selanjutnya (diproses/ditolak), apabila Ombudsman menolak aduan, maka akan disertai dengan penjelasan dan menyarankan kepada lembaga lain yang lebih berwenang; (3) melakukan penyelidikan tahap awal (tidak resmi) untuk mempercepat penyelesaian masalah, apabila masalah dapat diselesaikan pada tahap awal, maka 
penyelidikan resmi tidak perlu dilakukan; (4) apabila aduan merupakan masalah serius, maka Ombudsman akan memutuskan untuk melakukan penyelidikan ke lembaga terkait untuk memperoleh penjelasan dari lembaga tersebut (penyelidikan resmi); (5) setelah penyelidikan, maka Ombudsman akan membuat keputusan sementara baik pelapor atau terlapor yang berlaku tidak adil/menyalahgunakan kekuasaan, dan kedua belah pihak diberikan kesempatan untuk memberikan komentar sebelum keputusan akhir dibuat; (6) apabila perlu, maka Ombudsman dapat memberikan masukan dan saran kepada lembaga terkait (tidak ada unsur pemaksaan penerimaan saran); dan (7) apabila lembaga terkait merubah keputusannya atau menawarkan peninjauan kembali untuk menyelesaikan persolan tersebut secara personal maka Ombudsman tidak perlu campur tangan lagi.

Salah satu contoh penyelesaian aduan oleh Ombudsman New Zealand ialah terkait kasus District Health Board (DHB). Seorang pasien yang merupakan imigran legal pada awalnya, telah berubah statusnya kepada imigran ilegal dikarenakan ia telah keluar dari New Zealand untuk melanjutkan studi di negara lain. Ketika ia kembali ke New Zealand untuk melakukan operasi maka status VISA yang ia peroleh ialah Visa pengunjung.

Setelah operasi selesai dijalankan, ia menerima bon tagihan pembayaran sebesar $\$ 100.000$, hal ini terjadi akibat pemeriksaan status kelayakan pasien untuk didanai oleh dana publik diperiksa oleh DHB setelah operasi dilakukan. Hal ini menimbulkan perselisihan antara pasien dan DHB, karena sepengetahuan pasien, biaya operasi yang ia lakukan akan ditanggung oleh dana publik namun, sedangkan pihak DHB baru memeriksa kelayakan pasien tersebut setelah operasi selesai.

Aduan yang diterima oleh Ombudsman ialah kekecewaan yang dialami oleh pasien karena layak tidak layaknya ia menerima biaya dari dana publik diketahui setelah ia melakukan operasi. Sedangkan pihak DHB menyatakan bahwa perubahan statuslegal/ilegal dan layak tidak layaknya penerimaan biaya kesehatan dari dana publik sepenuhnya adalah tanggung jawab pasien. Untuk menyelesaikan perselisihan ini, Ombudsman memberikan saran bahwa sebaiknya pemeriksaan kelayakan pasien merupakan tanggung jawab bagi kedua belah pihak yaitu DHB dan pasien itu sendiri, oleh karena itu, DHB juga harus menyeleksi formulir kelayakan pasien untuk mendapatkan informasi yang jelas dan pasti mengenai status pasien dan pasien harus melaporkan kepada DHB terkait status terbarunya ketika ingin mendapatkan pembiayaan kesehatan dari dana publik.

Kinerja Ombudsman dalam menyelesaikan persoalan-persoalan pelayanan publik telah memberikan dampak positif bagi terselenggaranya sistem pelayanan publik yang berkualitas di New Zealand. Ombudsman terus meningkatkan kualitas kerjanya melalui pembentukan struktur aliran kerja baru, prosedur bantuan awal, proses penyelesaian awal serta memberikan pelayanan yang strategis untuk memastikan setiap lembaga negara memiliki struktur pelayanan yang efektif dan efesien.

Peningkatan jumlah aduan yang mencapai 29\% pada tahun 2012/2013 menunjukkan semakin besarnya kepercayaan masyarakat terhadap Ombudsman New Zealand, hal ini juga dibarengi dengan peningkatan hasil kerja sebesar 30\% dalam menyelesaikan pelbagai aduan masyarakat, masa penyelesaian 93\% kasus aduan dalam waktu 6 bulan turut menggambarkan pencapaian gemilang dari Ombudsman New Zealand dalam meningkatkan dan memperbaiki kualitas pelayanan publik oleh aparatur pemerintahan.

\section{Ombudsman di United Kingdom}

Ombudsman di United Kingdom di kenal dengan nama Parliamentary Commissioner fo Administration atau Parliamentary Ombudsman, Ombudsaman United Kingdom berdiri berdasarkan ketentuan dari Parliamentary Commission Act 1967. Latar belakang lahirnya Ombudsman di United Kingdom adalah untuk memenuhi tuntutan masyarakat luas terhadap 
perbaikan kualitas pelayanan publik serta dipengaruhi keberhasilan negara-negara Skandinavia melakukan reformasi birokrasi melalui lembaga Ombudsman.

Tidak jauh berbeda dengan Ombudsman lain di beberapa negara, Ombudsman United Kingdom dipimpin oleh seorang Commissioner yang dilantik oleh Crown dan menjabat selama lima tahun dan boleh dipilih kembali. Batasan umur bagi commissioner ialah 65 tahun namun, commissioner juga dapat diberhentikan apabila mengalami gangguan kesehatan atau diberhentikan atas kebijakan parlemen.

Awal pembentukannya, Ombudsman United Kingdom memiliki bidang kuasa yang sangat terbatas, yaitu hanya untuk menyelidiki aduan dari masyarakat yang mengalami ketidakadilan karena praktek maladministrasi seperti korupsi, diskriminasi, menyalahi aturan, bias, tidak mendapat pelayanan yang baik, dll yang dilakukan oleh aparatur pemerintah. Selain itu, Ombudsman hanya dapat menyelidiki lembaga-lembaga pemerintahan dan organisasi pemerintahan yang memiliki dampak langsung kepada masyarakat (Yardley, 1997: 98). Output dari penyelidikan yang dilakukan oleh Ombudsman United Kingdom berupa keputusan untuk membayar denda, permintaan maaf dan pemberian masukan kepada lembaga/aparatur terkait.

Tahun 1975, melalui UU Ombudsman Tahun 1968 telah dilakukan amandemen menjadi UU Ombudsman Tahun 1975, di mana melalui amandemen ini bidang kuasa penyelidikan Ombudsman diperluas hingga ke pemerintahan daerah serta struktur Ombudsman dipimpin lebih dari satu orang dan seorang dilantik sebagai ketua Ombudsman. Berdasarkan UU tersebut, maka kedudukan Ombudsman semakin kuat serta memiliki hierarki lembaga yang strategis karena terdiri dari kelompok pakar dalam pelbagai bidang keahlian.

Juli 1983, disahkannya Official Information Act 1983 telah memberikan kewenangan kepada Ombudsman untuk menyelidiki dan memeriksa keputusan mengenai permintaan untuk mendapatkan informasi/data resmi dari lembaga pemerintahan termasuk kementeriankementerian negara, state own enterprise, lembaga pendidikan dan kesehatan. Melalui undangundang ini, keterbukaan informasi/data dari lembaga-lembaga penting negara menggambarkan semakin tingginya usaha pemerintah United Kingdom untuk menerapkan sistem transparansi dalam pelbagai bidang. Selanjutnya, Ombudsman di United Kingdom terus berkembang mengikuti perkembangan pola pikir masyarakat yang semakin maju.

Perkembangan pola pikir masyarakat yang semakin kritis menjadi dasar bagi perluasan bidang kekuasaan Ombudsman di United Kingdom. Hal ini dapat terlihat dari semakin banyaknya bermunculan pelbagai macam lembaga Ombudsman yang khusus menyelidiki bidang-bidang tertentu, sepertiHealth Ombudsman (1973), Insurance Ombudsman (1981), Banking Ombudsman (1986),Pensions Ombudsman (1990), Legal Services Ombudsman (1990), Prison \& Probations Ombudsman (1994), Building Societies Ombudsman (1994), Funeral Ombudsman (1994), Independent Housing Ombudsman (1996), Corporate Estate Agents Ombudsman (1997), dan Local Government Ombudsman (2006).

Selain memiliki kuasa dalam bidang tertentu, Ombudsman United Kingdom juga memiliki batasan atau larangan untuk menyelidiki beberapa bidang, yaitu personal (private individuals) termasuk pengacara yang mewakili individu atau perusahaan, lembaga non-pemerintahan, keputusan peradilan, banding statutory ke peradilan terhadap suatu kasus, perilaku dan tindakan polisi, ketentuan dan syarat pelayanan yang diselenggarakan oleh angkatan bersenjata, tindakan dan keputusan oleh trustee berdasarkan Trustee Act 1956, keputusan menteri dan keputusan pemerintah daerah (Ombudsman memiliki hak untuk menyelidiki kementerian dan pemerintah daerah, namun tidak dapat mengubah atau mengintervensi keputusan lembaga tersebut).

Kinerja Ombudsman di United Kingdom terus menuai pujian dari pelbagai pihak. Pada tahun 1998 dan 1999, Ombudsman telah berhasil menyelesaikan aduan terhadap kebijakan kesehatan gratis yang menimpa pasien, di mana terdapat salah satu pasien lanjut usia yang harus membayar 47,000 pound untuk biaya perobatan padahal berdasarkan kebijakan negara, biaya perawatan dan pengobatan bagi orang lanjut usia adalah gratis. Selain itu, dalam masa satu 
tahun Ombudsman menerima hampir 900 aduan tentang maladministrasi, penyalahgunaan kuasa ataupun pelayanan yang kurang memuaskan (Jain, 1996: 174), hal ini menggambarkan besarnya kepercayaan publik terhadap lembaga Ombudsman di United Kingdom.

Lembaga Ombudsman di United Kingdom berperan besar dalam menyelesaikan pelbagai permasalahan yang melibatkan sistem pelayanan publik oleh aparatur pemerintahan, hal ini menggambarkan besarnya tingkat akuntabilitas dan transparansi yang diupayakan oleh pemerintah United Kingdom. Pelayanan publik merupakan sistem utama yang sangat penting dalam mewujudkan good governance. Teguhnya pengamalan akan prinsip-prinsip good governance dalam setiap pribadi aparatur negara akan menjadikan mereka sebagai pribadi yang lebih profesional.Oleh sebab itu, Ombudsman dalam hal ini hadir untuk mengontrol perilaku atau tindakan dari para aparatur pemerintah sehingga mereka tetap menjalankan tugasnya dalam koridor penegakan prinsip-prinsip good governance.

\section{SIMPULAN}

Ombudsman merupakan salah satu lembaga kekuasaan negara yang bertujuan untuk melindungi hak dan kepentingan masyarakat umum dari perlakuan yang tidak adil dalam sistem pelayanan publik dan peradilan. Keberhasilan Ombudsman Swedia telah mengantarkan perubahan sistem pelayanan publik secara global, hal ini dikarenakan konsep Ombudsman mulai diterapkan pada banyak negara.

Kehadiran Ombudsman telah menciptakan perubahan sistem birokrasi yang lebih demokratis dan lebih berkualitas. Perlindungan terhadap hak masyarakat serta kendali terhadap kinerja aparatur pemerintah yang dilakukan oleh Ombudsman menciptakan keseimbangan dalam sistem birokrasi negara. Tuntutan untuk terus melakukan reformasi birokrasi yang lebih baik terwujud dengan adanya peran besar Ombudsman.

Keberhasilan Ombudsman yang telah lama wujud di negara-negara Skandinavia ternyata dapat dicapai juga oleh negara diluar wilayah Skandinavia, dalam hal ini ialah New Zealand dan United Kingdom. Keberhasilan New Zealand dan United Kingdom dalam meningkatkan kredibilitas Ombudsman negaranya merupakan contoh nyata bahwa konsep Ombudsman dapat diterapkan di mana saja, dalam sistem apapun, oleh siapapun namun tetap untuk kepentingan dan melindungi hak-hak warga negara.

\section{REFERENSI}

Abraham, A. 2005. Redress in the round: remedying maladministration in central and local government. 5th. Report Session 2005-2006.

Antonius Sujata. 2003. Seminar dan lokakarya Pembentukan Lembaga Ombudsman Daerah. Yogyakarta.

Barron, A. And Scott, J. 1992. The Citizen's Charter Programme. London: Modern Law.

Caiden, Gerald E. 1983. International Handbook of the Ombudsman. Vol 1. Greenwood Press.

Cowan, J. 2001. The role of the Ombudsman in the risk management process. British Journal of Clinical Governance 6(3): 221-244.

Gregory, R \& Giddings, P. 1997. New challenges for a successful institution: the Ombudsman and the New Managerialism. Dalam Victor O. Ayeni. The Ombudsman around The World: essential elements, evolution and contemporary issues. London: Commonwealth Secretariat: 78-97.

Haller, W. 1998. The place of the Ombudsman in the world community. London: Butterworths Lexis Nexis.

Heede, K. 2000. European Ombudsman: redress and control at Union level. London: Butterworths Lexis Nexis.

Hill, Larry B. 1970. A Behavioral Analysis of the New Zealand Ombudsman. Thesis. 
Hill, Larry B. 1974. Institutionalization, the Ombudsman, and Bureaucracy. American Political Science Association Vol. 68 (1075-1085).

Jain, M. P. 1980. Administrative Law in Malaysia and Singapore. Singapore: Malayan Law Journal.

Lundvik U. 1968. Comment on the Ombudsman on Civil Affair. Dalam Donald C. Rowat (pnyt). The Ombudsman Citizen's Defender. Northmapton: John Dickens \& Co.

Nothey, J. F. 1968. New Zealand's Parliamentary Commissioner in the Ombudsman Citizen's Defender. Northmapton: John Dickens \& Co.

Owen, S. 1990. The Expanding Role of the Ombudsmanin the Administrative State. University of Toronto Law Journal. 40:3, 670-86.

Ramanathan, K. 2002. Konsep Asas Pentadbiran Awam. Kuala Lumpur: Dewan Bahasa dan Pustaka.

Rowat, D. C. 1968. The Ombudsman Citizen's Defender. Northampton: John Dickens \& Co.

Scott, I. 1994. Reforming the Commissioner for Administrative Complaints Office in Hong Kong. London: Butterworth.

Seneviratne, M. 1994. Ombudsman in the Public Services and Administrative Justice. Oxford: Oxford University Press.

Yardley, D. 1997. Ombudsman in United Kingdom. Journal of Malaysian and Comparative Law 32(3): 35-67. 